\title{
Antimicrobial activity, phenolic profile and role in the inflammation of propolis
}

\author{
João Carlos Silva ${ }^{\mathrm{a}}$, Sandra Rodrigues ${ }^{\mathrm{a}, \mathrm{b}}$, Xesús Feás ${ }^{\mathrm{c}}$, Leticia M. Estevinho ${ }^{\mathrm{a}, *}$ \\ ${ }^{a}$ Department of Biology and Biotechnology, Agricultural College of Bragança, Polytechnic Institute of Bragança, Campus Santa Apolónia, E 5301-855 Bragança, Portugal \\ ${ }^{\mathrm{b}}$ CIMO-Mountain Research Center, Portugal \\ ${ }^{\mathrm{c}}$ Department of Organic Chemistry, Faculty of Sciences, University of Santiago de Compostela, E-27002 Lugo, Spain
}

\section{A R T I C L E I N F O}

\section{Article history:}

Received 26 December 2011

Accepted 28 February 2012

Available online 7 March 2012

\section{Keywords:}

Antimicrobial activity

Hyaluronidase

Inflammation

Phenolic compounds

Propolis

\begin{abstract}
A B S T R A C T
Nowadays a great amount of information regarding chemical and biological aspects of bee products is available in the literature, but few data on its therapeutic uses are found. The aim of this study was to evaluate the phenolic profile, the in vitro antimicrobial activity and effect in the hyaluronidase enzyme (widely related with the inflammation process) of propolis harvested in Portugal. The efficacy of three extracts (hydro-alcoholic, methanolic and aqueous) was also compared. It was chosen the hydroalcoholic extract, because this was the most effective for extracting phenolic compounds. The antimicrobial activity was accessed in Gram-positive and Gram-negative bacteria and yeasts, isolated from different biological fluids and the results were then compared with the obtained for reference microorganisms. The propolis from Bragança was the one that possessed the highest polyphenols' content. The sample from Beja showed the less significant inhibition of the hyaluronidase enzyme. Concerning the antimicrobial activity, Candida albicans was the most resistant and Staphylococcus aureus the most sensitive. The reference microorganisms were more sensitive than the ones isolated from biological fluids.
\end{abstract}

(c) 2012 Elsevier Ltd. All rights reserved.

\section{Introduction}

Propolis is a beehive product prepared by bees of the Apis mellifera species, using resinous substances collected from various plants. These substances are mixed with $\beta$-glycosidase enzyme of their saliva, partially digested and added to bee wax to form the final product (Umthong et al., 2011). Propolis is used, by bees, as a sealing wax for filling cracks in beehives and as a protective barrier against the pathogenic microorganisms. It is considered the most important "chemical weapon" (Falcão et al., 2010).

The composition of this sticky resin and its physico-chemical properties, biological activities and therapeutic uses depend on the vegetation where the hives are placed, the climate and the variety of the queen (Quiroga et al., 2006). According to Kumazawa et al. (2004), in samples from Brazil terpenoids and prenylated derivatives of $p$-coumaric acids predominated whilst the samples from China and Europe mostly contained phenolic acid esters and flavonoids. In spite of the possible differences in composition, most propolis samples share considerable similarity in their overall chemical nature: $50 \%$ resin, 30\% wax, 10\% essential oils, 5\% pollen and $5 \%$ of other organic compounds (Gómez-Caravaca et al., 2006). In fact, propolis has more than 300 different compounds identified, such as: aliphatic acids, esters, aromatic acids, fatty acids, carbohydrates, aldehydes, amino acids, ketones, chalcones,

\footnotetext{
* Corresponding author. Tel.: +351 273 303342; fax: +351 273325405.

E-mail address: leticia@ipb.pt (L.M. Estevinho).
}

dihydrochalcones, terpenoids, vitamins and inorganic substances (Bankova et al., 2000).

This product has been used as remedy and as a food preservative by humans since ancient times (Umthong et al., 2011). In the last years, this product has been the subject of intensive studies, highlighting its biological and pharmacological properties, such as antibacterial (Velazquez et al., 2007) antiviral (Schnitzler et al., 2010), antioxidant (Moreira et al., 2008), hepatoprotective (Banskota et al., 2001), cariostatic (Libério et al., 2009) and anticancer (Valente et al., 2011). For these reasons, propolis awakened interest in the pharmaceutical industries, being introduced in products for human consumption, such as drinks, food and cosmetics (Moreira et al., 2008).

In addition, the emergence of antibiotic-resistant microorganisms, that are known by their dangerous action in wounds, decrease the treatment options. This led to an increase research of antimicrobial activity of natural products as possible alternatives (Morais et al., 2011). In fact, this was the most studied biological property of propolis. However, European propolis studies are scarce, and particularly in Portugal are non-existent.

This product is also used is medicine as an anti-inflammatory. Inflammation is a process by which the body's white blood cells and chemicals protect us from infection and foreign substances such as bacteria and viruses (Park et al., 2002). This process is associated with the liberation of inflammatory mediators, like prostaglandins, through enzymatic reactions, in which are involved: lipoxygenases, cyclooxygenases, phospholipase A2 and hyaluronidase (Braga et al., 2006). 
The hyaluronic acid is an important component of articular cartilage and plays an important role in tissues' renovation. Its degradation, by the hyaluronidase enzyme, may cause bone loss, inflammation and pain (Libby et al., 2002). As consequence, the determination of the hyaluronidase enzyme is an indirect way to assess the anti-inflammatory activity.

Both the anti-inflammatory and antimicrobial activities of Portuguese propolis have never been studied, even though beekeeping has great importance in the economy of this country.

In this context it is necessary to ensure the consistency of pharmacological and clinical research, to understand the biological activity of propolis as well as to achieve a reliable standardization on propolis types and to enhance product quality control.

In the present work and for the first time, it is evaluated the antimicrobial activity against multi-resistant microorganisms and the anti-inflammatory activity, assessed by the effect on the hyaluronidase enzyme, of propolis samples from Portugal. Simultaneously, it was also studied the effect of extraction solvents on this biological activities.

\section{Material and methods}

\subsection{Chemicals and reagents}

All the reagents were of analytical grade purity. Methanol $\left(\mathrm{CH}_{3} \mathrm{OH}\right)$ and ethano $\left(\mathrm{CH}_{3} \mathrm{CH}_{2} \mathrm{OH}\right)$ were supplied by Pronolab (Lisbon, Portugal). The Folin-Ciocalteu reagent, chloroform $\left(\mathrm{CHCl}_{3}\right)$, sodium carbonate $\left(\mathrm{Na}_{2} \mathrm{CO}_{3}\right)$, gentaminice and fluconazol were obtained from Merck (Darmstadt, Germany). Gallic acid and (+)-catechin were purchased from Sigma (St. Louis, MO, USA). The bovine testicular hyaluronidase (350 units) and the potassium salt of human umbilical cord hyaluronic acid were obtained from Sigma (St. Louis, MO, USA). The culture mediums were purchased from Himedia (Mumbai, India). The TTC solution (2,3,5-triphenyl-2H-tetrazolium chloride) was supplied by Fluka (Buchs, Switzerland). The other chemicals were obtained from Sigma Chemical Co. (St. Louis, MO, USA). High purity water (18 M $\Omega$ $\mathrm{cm}$ ), used in all experiments, was obtained from a Milli-Q purification system (Millipore, Bedford, MA, USA).

\subsection{Propolis samples}

Propolis samples were collected by beekeepers in the fall of 2010 from A. mellifera hives located in different zones of Portugal: Bragança $\left(42^{\circ} 48^{\prime} \mathrm{N} ; 6^{\circ} 45^{\prime} \mathrm{W}\right.$ ); Coimbra $\left(40^{\circ} 15^{\prime} \mathrm{N} ; 8^{\circ} 27^{\prime} \mathrm{W}\right)$ and Beja $\left(38^{\circ} 1^{\prime} \mathrm{N}, 7^{\circ} 52^{\prime} \mathrm{W}\right)$. Three samples $(n=3)$ were collected from each place and all the analysis were performed in triplicate. They were obtained after the honey extraction by scratching the hive walls and frames. Upon receipt, each sample was inspected in order to find rests of bees, wood, plant, pupa of moth, among others. The major visible impurities were removed from the samples. Each sample was weighed and frozen at $-20^{\circ} \mathrm{C}$ until analysis.

\subsection{Palynological identification}

Palynological processing of the samples followed the standard methodology, described in detail previously by Moreira et al. (2008). In briefly, $0.5 \mathrm{~g}$ of scraped propolis was extracted overnight with ethanol. Next, the sediment was treated with $\mathrm{KOH}(10 \%)$, sonicated for $15 \mathrm{~min}$. and sieved through a 20 mesh stainless steel screen to eliminate large fragments. In this stage, three propolis microscope slides were mounted with sediment obtained after centrifugation $(10,000 \mathrm{~g}$ for $1 \mathrm{~min})$ for observation of plant trichomes and other organic residues that may be destroyed in sequence. Then acetolysis was applied, and two additional microscope slides were prepared using glycerin jelly, one stained with basic fuchsine and the other without stain. Approximately 300 pollen grains in each sample were counted. Pollen grain identification was performed by optical microscope with total magnification $(\times 400$ and $\times 1000)$. A reference collection of CIMO - Mountain Research Centre (Agricultural College of Bragança) and different pollen morphology guides (CUPOD, Cambridge University Palynological Online Database) were used for the recognition of the pollen types.

\subsection{Extraction procedure}

\subsubsection{Aqueous extract}

Propolis (5 g) was chopped into small pieces and extracted with $50 \mathrm{~mL}$ of water $\left(80^{\circ} \mathrm{C}\right.$ ) for $3 \mathrm{~h}$ (Midorikawa et al., 2001). Afterwards, the resulting mixture was filtered and the residue was re-extracted in the same conditions. The next step was the mixture of both filtrated solutions, which were then frozen at $-20^{\circ} \mathrm{C}$.

\subsubsection{Methanolic extract}

The propolis samples were broken into small pieces and homogenized. The samples were extracted with $80 \%$ of methanol/water $(1 / 10, v / v)$ at $70^{\circ} \mathrm{C}$ for $1 \mathrm{~h}$. The mixtures were filtered, and the residue was re-extracted following the same procedure. After, the filtrated solutions were combined, concentrated and frozen at $-20^{\circ} \mathrm{C}$.

\subsubsection{Hydro-alcoholic extract}

Prior to the extraction, the propolis was grounded and homogenized. The samples were extracted with $80 \%$ of ethanol/water $(1 / 10, v / v)$ at $70{ }^{\circ} \mathrm{C}$ for $1 \mathrm{~h}$, the resulting mixtures were filtered, and the residues were re-extracted in the same conditions. After the second extraction, the filtrated solutions were combined, concentrated and frozen at $-20^{\circ} \mathrm{C}$.

\subsection{Total phenolics and flavonoids}

The total phenolic content in the extracts were recorded using the Folin-Ciocalteu method as described by Moreira et al. (2008). Briefly, a dilute solution of each propolis in $\mathrm{MeOH}$ (MeOH-propolis; $500 \mu \mathrm{L}$ of $1: 10 \mathrm{~g} / \mathrm{mL}$ ) was mixed with $500 \mu \mathrm{L}$ of Folin-Ciocalteu reagent and $500 \mu \mathrm{L}$ of $\mathrm{Na}_{2} \mathrm{CO}_{3}(10 \% \mathrm{w} / \mathrm{v})$. After incubation in dark at room temperature for $1 \mathrm{~h}$, the absorbance of the reaction mixture at $700 \mathrm{~nm}$ was determined against the blank (the same mixture without the $\mathrm{MeOH}$-propolis) using a Unicam Helios Alpha UV-visible spectrometer (Thermo Spectronic, Cambridge, UK). Galic Acid standard solutions $\left(0.01 \times 10^{-3}-0.08 \times 10^{-3} \mathrm{M}\right)$ were used for constructing the calibration curve $\left(y=2.3727 x+0.0022 ; R^{2}=0.9998\right)$. Total phenols content were expressed as $\mathrm{mg}$ of Galic Acid equivalents per $\mathrm{g}$ of propolis (GAEs).

For flavonoids' contents the aluminium chloride method was used. In briefly, MeOH-propolis $(250 \mu \mathrm{L})$ was mixed with $1.25 \mathrm{~mL}$ of distilled $\mathrm{H}_{2} \mathrm{O}$ and $75 \mu \mathrm{L}$ of a $5 \% \mathrm{NaNO}_{2}$ solution. After $5 \mathrm{~min}, 150 \mu \mathrm{L}$ of a $10 \% \mathrm{AlCl}_{3} \cdot \mathrm{H}_{2} \mathrm{O}$ solution was added. After $6 \mathrm{~min}, 500 \mu \mathrm{L}$ of $1 \mathrm{M} \mathrm{NaOH}$ and $275 \mu \mathrm{L}$ of distilled $\mathrm{H}_{2} \mathrm{O}$ were added to the mixture and vortexed. The solution was well mixed and the intensity of pink colour was measured at $510 \mathrm{~nm}$. Catechin standard solutions $\left(0.022 \times 10^{-3}-0.34 \times 10^{-3} \mathrm{M}\right)$ were used for constructing the calibration curve $(y=0.9689 x-0.0092$; $R^{2}=0.9987$ ). Total flavonoids content were expressed as $\mathrm{mg}$ of catechin equivalents per $g$ of propolis (CAEs).

\subsection{UV-visible absorption spectroscopy}

The determination of the UV-visible spectra of the extracts (aqueous, methanolic and hydro-alcoholic) was performed according to Koo et al. (2002). Twenty-five microlitre of each propolis extract were diluted into $30 \mathrm{~mL}$ of ethanol. The absorption spectra were determined in the wavelength range from 200 to $500 \mathrm{~nm}$.

\subsection{Anti-inflammatory activity - hyaluronidase assay}

The inhibition of hyaluronidase activity was determined using de method described by Park et al. (1998). The reaction mixture is constituted by $50 \mu \mathrm{L}$ of propolis' extract and $50 \mu \mathrm{L}$ (350 units) of hyaluronidase enzyme (Type IV-S: bovine testes), was incubated at $37^{\circ} \mathrm{C}$ for $20 \mathrm{~min}$. Then, calcium chloride was added $\left(1.2 \mu \mathrm{L}, 2.5 \times 10^{-3} \mathrm{M} / \mathrm{L}\right)$ to activate the enzyme and the mixture was incubated at $37{ }^{\circ} \mathrm{C}$ for $20 \mathrm{~min}$. To start the reaction $0.5 \mathrm{~mL}$ of hyaluronic acid sodium salt $(0.1 \mathrm{M} / \mathrm{L})$ were added. The mixture was incubated at $37^{\circ} \mathrm{C}$ for $40 \mathrm{~min}$. After this, $0.1 \mathrm{~mL}$ of potassium tetraborate $0.8 \mathrm{M}$ was added and it was incubated in waterbath at ebullition for $3 \mathrm{~min}$. The mixture was placed at $10^{\circ} \mathrm{C}$ and $3 \mathrm{~mL}$ of $p$-dimethylaminebenzaldehyde were added. Afterwards, it was incubated at $37^{\circ} \mathrm{C}$ for $20 \mathrm{~min}$. Finally, the absorbance was measured at $585 \mathrm{~nm}$ using water as control. All the tests were performed in triplicate.

\subsection{Antimicrobial activity}

The microorganisms used as test organisms are presented in Table 1. The microorganisms were isolated from biological fluids (in the Hospital Centre) and identified in the Microbiology Laboratory of Escola Superior Agrária de Braganca. It were also used reference strains, obtained from the authorized distributor of ATCC (LGC Standards S.L.U., Barcelona.) The isolates were stored in Muller-Hinton medium plus $20 \%$ glycerol at $-70{ }^{\circ} \mathrm{C}$, before experimental use. The inoculum for the assays were prepared by diluting cell mass in $0.85 \% \mathrm{NaCl}$ solution, adjusted to $0.5 \mathrm{MacFar}-$ land scale, confirmed by spectrophotometrical reading at $580 \mathrm{~nm}$ for bacteria and $640 \mathrm{~nm}$ for yeasts. Cell suspensions were finally diluted to $10^{4} \mathrm{CFU} / \mathrm{mL}$ in order to use them in the activity assays. Antimicrobial tests were carried out according to Morais et al. (2011), using Nutrient Broth (NB) or Yeasts Peptone Dextrose (YPD) on microplate (96 wells). Propolis extracts were diluted in dimethylsulfoxide (DMSO) and transferred into the first well, and serial dilutions were performed. The inoculum was added to all wells and the plates were incubated at $37^{\circ} \mathrm{C}$ for $24 \mathrm{~h}$ (bacteria) and $25^{\circ} \mathrm{C}$ for $48 \mathrm{~h}$ (yeast). Fluconazol and gentamicine were used as controls. In each experiment a positive control (inoculated medium) and a negative control (medium) and DMSO control (DMSO with inoculated medium) was introduced. Antimicrobial activity was detected by adding $20 \mu \mathrm{L}$ of $0.5 \%$ TTC solution. The Minimum Inhibitory Concentration (MIC) was defined as the lowest 
Table 1

Microorganisms used in the present study to test antimicrobial activity of propolis extacts.

\begin{tabular}{|c|c|c|}
\hline Microorganism & Reference & Origin \\
\hline Staphylococcus aureus & ATCC $6538^{\mathrm{TM}}$ & $\begin{array}{l}\text { Reference } \\
\text { culture }\end{array}$ \\
\hline $\begin{array}{l}\text { Methicillin-resistant Staphylococcus } \\
\text { aureus }\end{array}$ & ESA 175 & Pus \\
\hline $\begin{array}{l}\text { Methicillin-resistant Staphylococcus } \\
\text { aureus }\end{array}$ & ESA 159 & Expectoration \\
\hline Pseudomonas aeruginosa & $\begin{array}{l}\text { ATCC } \\
15442^{\text {TM }}\end{array}$ & $\begin{array}{l}\text { Reference } \\
\text { culture }\end{array}$ \\
\hline $\begin{array}{l}\text { Imipenem-resistant Pseudomonas } \\
\text { aeruginosa }\end{array}$ & ESA 22 & Expectoration \\
\hline $\begin{array}{l}\text { Imipenem-resistant Pseudomonas } \\
\text { aeruginosa }\end{array}$ & ESA 23 & $\begin{array}{l}\text { Gingival } \\
\text { exudates }\end{array}$ \\
\hline Escherichia coli & $\begin{array}{l}\text { ATCC } \\
29998^{\text {TM }}\end{array}$ & $\begin{array}{l}\text { Reference } \\
\text { culture }\end{array}$ \\
\hline Cephalosporins-resistant Escherichia coli & ESA 37 & Urine \\
\hline Cephalosporins-resistant Escherichia coli & ESA 54 & Hemoculture \\
\hline Candida albicans & $\begin{array}{l}\text { ATCC } \\
10231^{\mathrm{TM}}\end{array}$ & $\begin{array}{l}\text { Reference } \\
\text { culture }\end{array}$ \\
\hline Fluconazol-resistant Candida albicans & ESA 500 & Faeces \\
\hline Fluconazol-resistant Candida albicans & ESA 502 & Urine \\
\hline
\end{tabular}

ESA (Escola Superior Agrária de Bragança); ATCC (American Type Culture Collection).

concentration of propolis extract that inhibited visible growth, as indicated by the TCC staining (dead cells are not stained by TTC). All the tests were performed in triplicate $(n=3)$. The results are expressed as $\mathrm{mg} / \mathrm{mL}$.

\subsection{Statistical analysis}

Each propolis sample was analysed in triplicate. Results are shown as arithmetic mean values \pm standard deviation. In each parameter, the differences between propolis were analysed using one-way analysis of variance (ANOVA) followed by Tukey's HSD. P values less than or equal to 0.05 were evaluated as statistically significant. This treatment was carried out using SAS v. 9.1.3 program (SAS Inc., New York City, USA).

\section{Results and discussion}

\subsection{Palynological identification}

Results of bee pollens' profile analysis allow scientists to infer the vegetation present in the area and to date and ascertain any biodiversity change, as for example, the presence and distribution of invasive or exotic plants (Morais et al., 2011). The quantification of the pollens' present in propolis aims to determinate its floral origin. In fact, this origin is one of the factors that influence the bioactive properties of this product. In accordance with melissopalynological criteria (Louveaux et al., 1970), the following designations of pollen frequency were used: PD for dominant (>45\%), PA for accessory (15-45\%), and PI for isolated pollen loads but important to characterize the phytogeographical origin of the sample (3-15\%).

The pollen profiles obtained for the three samples are presented in Fig. 1. Marked differences were found among the samples. In the propolis from Bragança, with brown colour, the botanical specie with higher percentage was Erica sp. $(47.29 \% \pm 5.89)$, followed by Castanea sativa $(21.08 \% \pm 2.27)$. Concerning the sample from Coimbra (dark yellow propolis), Populus tremula was the dominant specie $(55.10 \% \pm 5.87)$, however, the species Salix sp. $(35.82 \% \pm 3.78)$ and Rubus sp. $(9.08 \% \pm 0.99)$ were also found. In propolis from Beja (green-brown colour), Eucalyptus sp. was the predominant pollen, with a percentage of 60.02 and a standard deviation of 5.89. Pollens from Rubus sp. and P. tremula were found in all the analysed samples. The pollens' profile was significantly different for all the samples under study $(p<0.05)$.

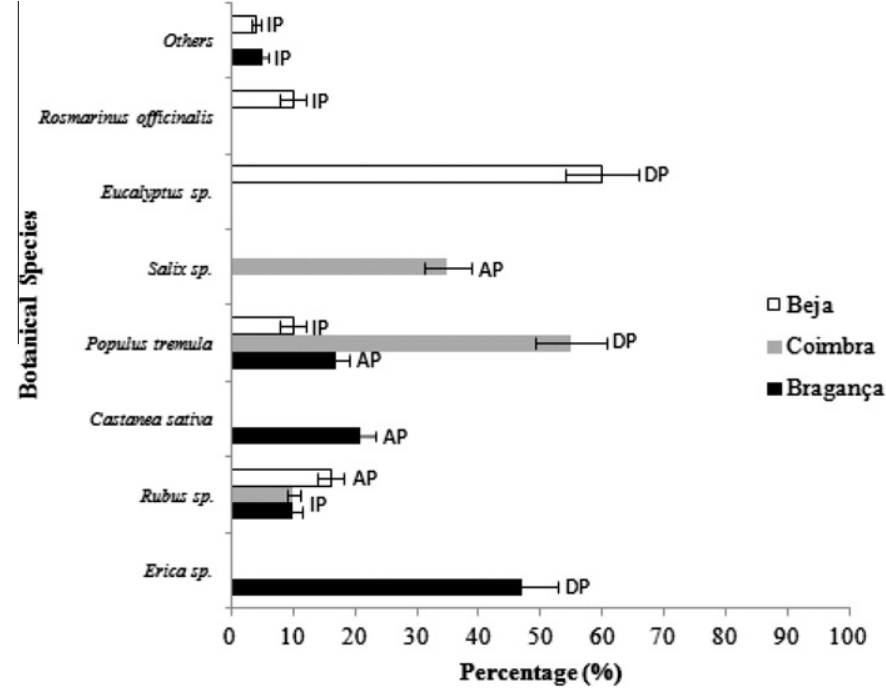

Fig. 1. Palynological spectrum of bee pollen samples. DP - Dominant Pollen ( $>45 \%)$; AP - Acessory Pollen (15-45\%); IP - Isolated Pollen (<15\%).

\subsection{Total phenolics and flavonoids}

According to the literature (Bankova et al., 2000; Gómez-Caravaca et al., 2006), the majority of compounds already identified in propolis are polyphenols. These compounds have been extracted using different solvents: water, methanol and ethanol. In this context, the efficiency of these substances was assessed.

Table 2 shows the contents of phenolic and flavonoids compounds present in the different propolis extracts (hydro-alcoholic, methanolic and aqueous), for each place (Bragança, Coimbra and Beja). For all the propolis studied ( $n=3$ ), water was the less effective solvent. In fact, the concentration of phenolics and flavonoids of the aqueous extract was lower than the concentration found in the other extracts, which showed significantly higher amounts of those compounds. The hydro-alcoholic extract, that is not as toxic as methanolic, was found to be the best solvent for the compounds under study. It extracted $\approx 4.34$ times more total phenolics than the aqueous extract and $\approx 1.52$ times more than the methanolic extract. The flavonoids' concentration obtained for the hydro-alcoholic extract was significantly higher than the amounts extracted by methanol and by water.

Concerning the different places, propolis from Bragança was the one that possessed higher concentration of total phenolics $(277.17 \pm 7.50)$ and flavonoids $(142.32 \pm 4.52)$, followed by Coimbra's propolis. For a $95 \%$ confidence interval $(p=0.05)$, significant

Table 2

Concentration $(\mathrm{mg} / \mathrm{g})$ of phenolics and flavonoids in propolis extracts from different locations $(n=27)$

\begin{tabular}{llcc}
\hline & Extract & Phenolics $(\mathrm{mg} / \mathrm{g})$ & Flavonoids $(\mathrm{mg} / \mathrm{g})$ \\
\hline Bragança $^{\mathrm{x}}$ & Hydro-alcoholic & $277.17 \pm 7.50^{\mathrm{a}}$ & $142.32 \pm 4.52^{\mathrm{a}}$ \\
& Methanolic & $181.31 \pm 4.71^{\mathrm{b}}$ & $135.51 \pm 4.18^{\mathrm{b}}$ \\
& Aqueous & $72.15 \pm 1.20^{\mathrm{c}}$ & $42.30 \pm 2.10^{\mathrm{c}}$ \\
Coimbra $^{\mathrm{y}}$ & Hydro-alcoholic & $157.31 \pm 1.52^{\mathrm{a}}$ & $98.30 \pm 6.54^{\mathrm{a}}$ \\
& Methanolic & $102.32 \pm 0.59^{\mathrm{b}}$ & $55.25 \pm 0.33^{\mathrm{b}}$ \\
& Aqueous & $35.15 \pm 0.88^{\mathrm{c}}$ & $29.0 \pm 1.00^{\mathrm{c}}$ \\
Beja $^{\mathrm{z}}$ & Hydro-alcoholic & $87.15 \pm 4.80^{\mathrm{a}}$ & $25.15 \pm 2.53^{\mathrm{a}}$ \\
& Methanolic & $58.61 \pm 3.10^{\mathrm{b}}$ & $13.62 \pm 2.49^{\mathrm{b}}$ \\
& Aqueous & $18.52 \pm 1.35^{\mathrm{c}}$ & $6.34 \pm 0.55^{\mathrm{c}}$
\end{tabular}

a, b, c - Means with different letters are significantly different for microorganisms $\mathrm{x}, \mathrm{y}, \mathrm{z}-$ Means with different letters are significantly different for locations. 
differences were found among the samples with different origins (Table 2).

Globally, our results are in agreement with the data obtained by Moreira et al. (2008), who studied propolis from the northeast of Portugal. However, Miguel et al. (2010) obtained inferior values when analyzing propolis from the south of the same country. This discrepancy may be due to the great distances between the local of origin and the different apicultural practices. In fact, our data suggest that propolis from different places have different concentrations of polyphenols.

The values obtained for catechin and gallic acid, which were used as standards, were bellow the concentration obtained in this study for flavonoids. This is in agreement with the reported by Falcão et al. (2010) and Popova et al. (2004) that refer the minor importance of gallic acid in propolis from temperate zones. This phenolic acid is mostly found in tropical samples. In propolis from the Mediterranean region prevailed flavonoids and esters of caffeic and ferulic acids.

Considering that the hydro-alcoholic extract was the most effective, it was used in all the assays performed after.

\subsection{UV-visible absorption spectroscopy}

The absorption spectrum of the hydro-alcoholic extracts is shown in Fig. 2. The spectrums of the analysed propolis were similar, with the maximum absorption between 290 and $370 \mathrm{~nm}$. In agreement with Castro et al. (2007) the absorption profile between the 270 and $330 \mathrm{~nm}$ (wavelength) are attributed to flavonoids and phenolics. This suggests that the polyphenols are the biggest constituents of propolis. The small differences $(p=0.103)$ in absorbance values reflect the concentrations of phenolic and flavonoids present in each propolis: propolis from Bragança possesses the highest amount of polyphenols and also has the highest value of absorbance.

\subsection{Anti-inflammatory activity}

The inflammation process involves production and/or release of mediators from neurons or damaged tissues, which are responsible for different responses including pain. Scavenging of free radicals, generated by neutrophils in inflammatory processes, is the princi- pal mechanism of conventional anti-inflammatory drugs, and is also a known property of propolis (Paulino et al., 2003). In this study, we verified that all the extracts inhibited the hyaluronidase enzyme in a dose-dependent manner (Fig. 3). The propolis that showed higher inhibitory activity was the one from Bragança and the product from Beja was the less effective. When the concentration of propolis was $25 \mathrm{mg} / \mathrm{mL}$, the percentage of inhibition was $75.79 \pm 2.17 \%$ (Bragança), $70.48 \pm 3.12 \%$ (Coimbra) and $53.76 \pm$ $2.87 \%$ (Beja).

Concerning the inhibition, it were not found significant differences between the samples from Bragança and Coimbra, despite the differences amongst the polyphenols' concentrations. This suggests that these compounds are not the only factor responsible for the bioactive properties of this beehive product. In fact, other constituents like vitamins and proteins are also involved in this activity (Almeida-Muradian et al., 2005).

The action mechanisms of this product haven't yet been figured out. However, Hu et al. (2005) claimed that propolis inhibited the

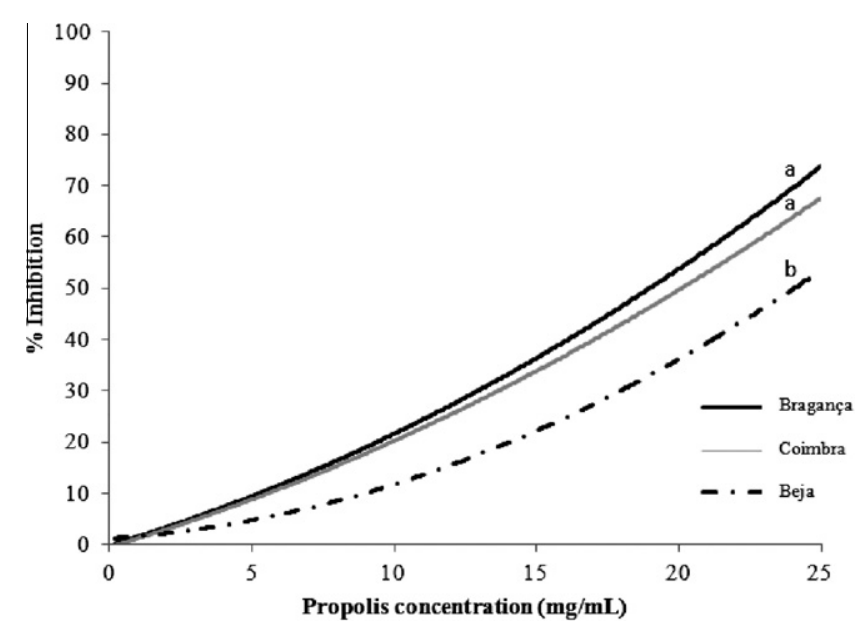

Fig. 3. Inhibition of the activity of Hyaluronidase by the propolis extracts for each concentration. The letters $(\mathrm{a}, \mathrm{b})$ represent which samples are different by Tukey test with significance of $p=0.05$.

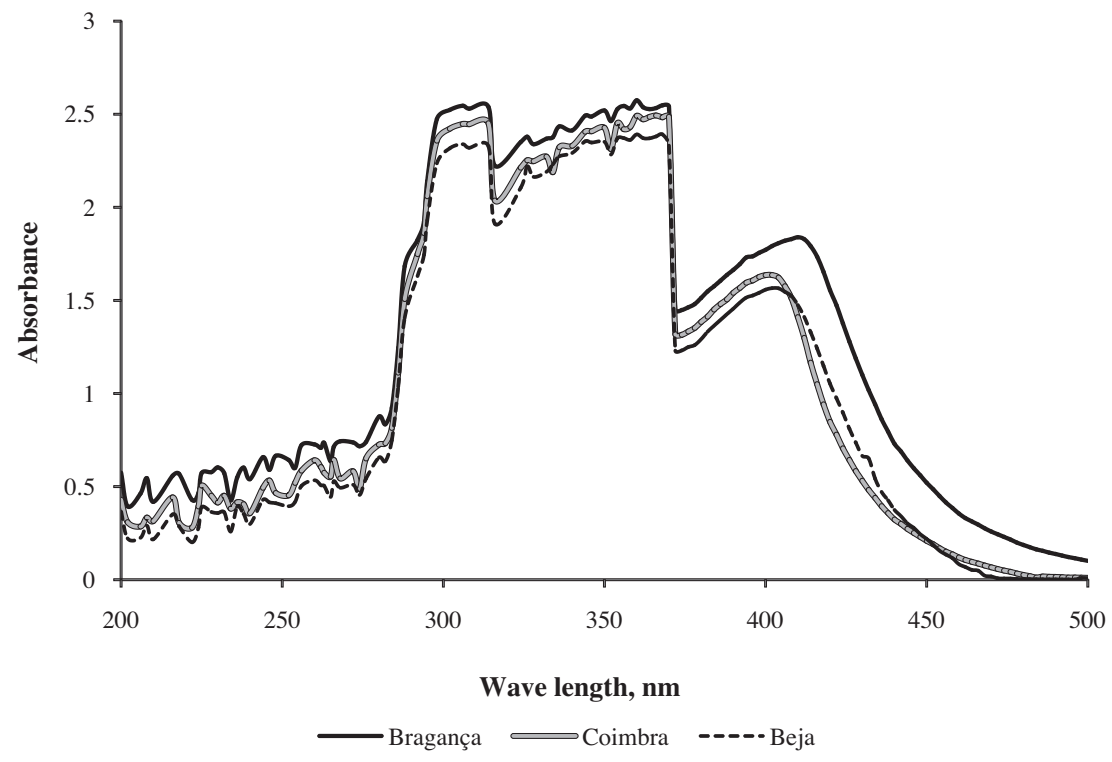

Fig. 2. Absorption spectra of the ethanolic propolis extracts from different locations. 
Table 3

Minimum Inhibitory Concentration $(\mathrm{mg} / \mathrm{mL})$ for the studied microorganisms and relation between the same specie (reference culture and isolated microorganisms), independently of propolis' origin.

\begin{tabular}{|c|c|c|}
\hline Microorganism & $\begin{array}{l}\text { Mean } \pm \text { standard } \\
\text { deviation }\end{array}$ & $\begin{array}{l}\text { Microorganism's effect ( } p \text { - } \\
\text { value) }\end{array}$ \\
\hline S. aureus ATCC & $0.59 \pm 0.30 b$ & $(<0.001)^{* * *}$ \\
\hline S. aureus ESA 175 & $1.36 \pm 0.74 a$ & \\
\hline S. aureus ESA 159 & $1.72 \pm 0.87 a$ & \\
\hline P. aeruginosa ATCC & $1.56 \pm 0.67 b$ & $(0.035)^{*}$ \\
\hline $\begin{array}{l}\text { P. aeruginosa ESA } \\
22\end{array}$ & $2.56 \pm 1.07 a$ & \\
\hline $\begin{array}{l}\text { P. aeruginosa ESA } \\
23\end{array}$ & $2.81 \pm 1.18 \mathrm{a}$ & \\
\hline E. coli ATCC & $3.19 \pm 0.93 b$ & $(0.043)^{*}$ \\
\hline E. coli ESA 37 & $4.94 \pm 1.42 \mathrm{a}$ & \\
\hline E. coli ESA 54 & $4.86 \pm 1.90 a$ & \\
\hline C. albicans ATCC & $13.19 \pm 7.21 \mathrm{a}$ & NS (0.968) \\
\hline $\begin{array}{l}\text { C. albicans ESA } \\
500\end{array}$ & $13.44 \pm 8.23 \mathrm{a}$ & \\
\hline $\begin{array}{l}\text { C. albicans ESA } \\
502\end{array}$ & $13.90 \pm 7.512 \mathrm{a}$ & \\
\hline
\end{tabular}

The letters $\mathrm{a}$ and $\mathrm{b}$ symbolise means that are significantly different.

NS - non-significant.

* $p<0.05$.

$p<0.001$.

increase of prostaglandin $E_{2}$ and nitric oxide production, suggesting that both effects could decrease the inflammatory process.

\subsection{Antimicrobial activity}

Some of the common nosocomial infections are urinary tract infections, respiratory pneumonia, surgical site wound infections, bacteremia, gastrointestinal and skin infections. According to the Center for Disease Control and Prevention (Atlanta, USA), the most common pathogens that cause these infections are Staphylococcus aureus (Gram-positive), Pseudomonas aeruginosa (Gram-negative) Escherichia coli (Gram-negative) and Candida albicans (yeast). As it is very difficult to eliminate these microorganisms, due to their resistance to most antimicrobial agents, we decided to test the effect of propolis against them. Table 3 and Fig. 4 depict the obtained results. All the propolis studied presented antimicrobial activity, but this effect depended on the origin of the product and the microorganism under study. Significant differences were found between the sample from Beja and the samples from Coimbra and Bragança $(p<0.001)$. The activity of the last two samples didn't differ significantly $(p=0.142)$. For all the microorganisms, the propolis from Beja was the least effective. Concerning the microorganisms, the post hoc test indicates that $C$. albicans (all the strains) was significantly different from the others $(p<0.001)$. Once its MIC value was the highest $(13.19 \pm 7.21 ; 13.44 \pm 8.23$; $13.90 \pm 7.512 \mathrm{mg} / \mathrm{mL}$ ), it was the most resistant to the propolis' effect. The $S$. aureus was the most sensitive to the propolis' effect (MIC: $0.59 \pm 0.30 ; 1.36 \pm 0.74 ; 1.72 \pm 0.87 \mathrm{mg} / \mathrm{mL}$ ). As it can be seen in Table 3 , the propolis showed greater activity against Gram-positive bacteria than against Gram-negative. These results are in agreement with those of Vardar-Ünlü et al. (2008) and Kim and Chung (2011). This may be explained by the structural differences of the bacterial cell wall of Gram-positive and Gram-negative bacteria. Gram-negative bacteria, apart from the cell membrane, possess an additional outer layer membrane, which consists of phospholipids, proteins and lipopolysaccharides, and this membrane is impermeable to most molecules (Silici and Kutluca, 2005).

Even though the action mechanisms aren't fully understood, the antimicrobial activity is potentially due to rutin, quercetin, naringenin. These compounds increase the permeability of the inner bacterial membrane, nullifying its potential, decreasing the ATP production, the membrane transport and its mobility (Tsuchiya and Iinuma, 2000). In addition, they inhibit the DNA gyrase which involves in the mechanism of DNA and RNA synthesis of bacteria (Mirzoeva et al., 1997).

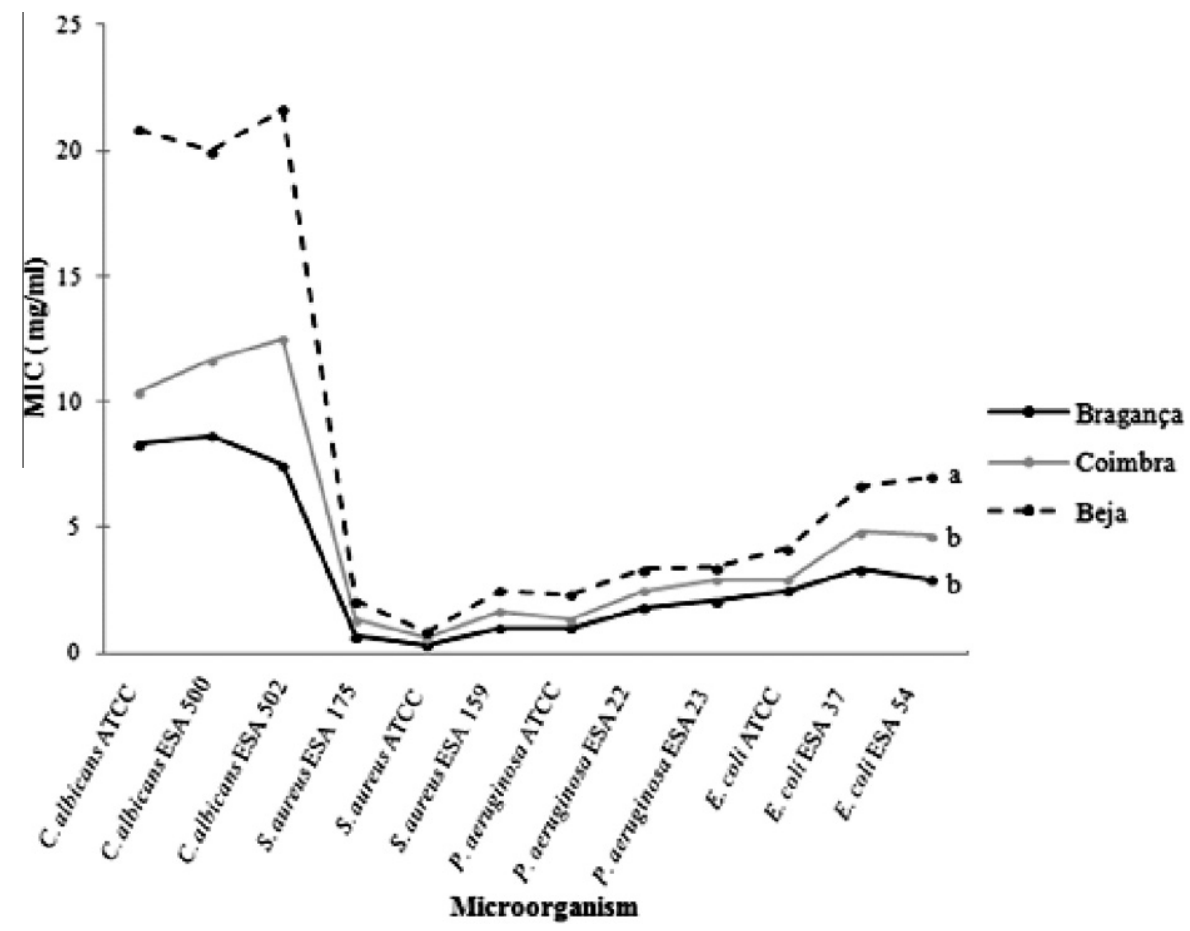

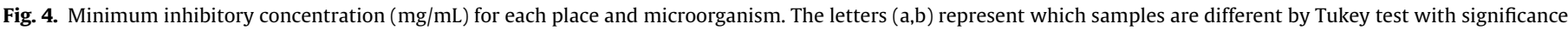
of $p=0.05$. 
Globally, the drug-resistance strains were more resistant to the hydro-alcoholic extract action than the reference strains (Table 3 ). Apart from Candida, it were found significant differences between the reference stains and the ones isolated from biological fluids.

These results, which are corroborated by Onlen et al. (2007), suggest that the simultaneous use of propolis and antibiotics may reduce the acquisition of resistances and consequently avoid the use of more powerful antibiotics.

\section{Conclusions}

This study is the first approach to the antimicrobial and antiinflammatory activities of Portuguese propolis. It was verified that the water and ethanol is the best solvent for polyphenols (hydroalcoholic extract). It was demonstrated that the hydro-alcoholic propolis' extract, at very low concentrations can inhibit the hyaluronidase enzyme. More experiments in relation to this theme should be done to confirm the anti-inflammatory activity of propolis extract. In addition, propolis evidenced considerable antimicrobial activity, as it inhibited the growth of yeasts, Gramnegative and Gram-positive bacteria, being the latter the most sensitive to this beehive product's action. Overall, these findings support that Portuguese propolis is a promising therapeutic agent in diseases caused by drug-resistant microorganisms and in inflammations' prevention.

In further studies, the next step seems to be the elucidation of the propolis' action mechanisms and the compounds responsible for these beneficial properties, in order to take advantage of this natural product, which is, apparently free of any non-desirable secondary effects.

\section{Conflict of Interest}

The authors declare that there are no conflicts of interest.

\section{References}

Almeida-Muradian, L.B., Pamplona, L.C., Coimbra, S., Barth, O., 2005. Chemica composition and botanical evaluation of dried bee-pollen pellets. Journal of Food Composition and Analysis 18, 105-111.

Bankova, V.S., De Castro, S.L., Marcucci, M.C., 2000. Propolis: recent advances in chemistry and plant origin. Apidologie 31, 3-15.

Banskota, A.H., Tezuka, Y., Adnyana, I.K., Ishii, E., Midorikawa, K., Matsushige, K. Kadota, S., 2001. Hepatoprotective and anti-Helicobacter pylori activities of constituents from Brazilian propolis. Phytomedicine 8, 16-23.

Braga, P.C., Sasso, M.D., Culici, M., Bianchi, T., Bordoni, L., Marabini, L., 2006. Antiinflammatory activity of thymol: inhibitory effect on the release of human neutrophil elastase. Pharmacology 77, 130-136.

Castro, M.L., Cury, J.A., Rosalen, P.L., Alencar, S.M., Ikegaki, M., Duarte, S., Koo, H. 2007. Própolis do sudeste e nordeste do brasil: influência da sazonalidade na atividade Antibacteriana e composição fenólica. Quimica Nova 30, 1512-1516.

CUPOD, Cambridge University Palynological Online Database. The resource can be found at: <http://www.quaternary.group.cam.ac.uk/pollen/>

Falcão, S.I., Vilas-Boas, M., Estevinho, L.M., Barros, C., Domingues, M.R., Cardoso, S. 2010. Phenolic characterization of Northeast Portuguese propolis: usual and unusual compounds. Analytical and Bioanalytical Chemistry 396, 887-897.

Gómez-Caravaca, A.M., Gómez-Romero, M., Arráez-Román, D., Segura-Carretero, A. Fernández-Gutiárrez, A., 2006. Advances in the analysis of phenolic compounds in products derived from bees. Journal of Pharmaceutical and Biomedical Analysis 41, 1220-1234.

Hu, F., Hepburn, H.R., Li, Y., Chen, M., Radloff, S.E., Daya, S., 2005. Effects of ethanol and water extracts of propolis (bee glue) on acute inflammatory animal models. Journal of Ethnopharmacology 100, 276-283.
Kim, Y.H., Chung, H.J., 2011. The effects of Korean Propolis against foodborne pathogens and transmission electron microscopic examination. New Biotechnology 28, 713-718.

Koo, H., Rosalen, P.L., Cury, J.A., Park, Y.K., Bowen, E.H., 2002. Effects of compounds found in propolis in Streptococcus mutans growth and glusyltransferaseactivity. Antimicrobial Agents and Chemotherapy 46, 1302-1309.

Kumazawa, S., Hamasaka, T., Nakayama, T., 2004. Antioxidant activity of propolis of various geographic origins. Food Chemistry 84, 329-339.

Libby, P., Ridker, P.M., Maseri, A., 2002. Inflammation and atherosclerosis. Circulation 105, 1135-1143.

Libério, S.A., Pereira, A.L., Araújo, M.J., Dutra, R.P., Nascimento, F.R., Monteiro-Neto, V., Ribeiro, M.N., Gonçalves, A.G., Guerra, R.N., 2009. The potential use of propolis as a cariostatic agent and its actions on mutans group streptococci. Journal of Ethnopharmacology 125, 1-9.

Louveaux, J., Maurizia, A., Vorwohl, G., 1970. Methods of melissopalynology by International Commission for Bee Botany of IUBS. Bee World 51, 125-138.

Midorikawa, K., Banskota, A.H., Tezuka, Y., Nagaoka, T., Matsushige, K., Message, D., Huertas, A.A.G., Kadota, S., 2001. Liquid chromatography-mass spectrometry analysis of propolis. Phytochemical Analysis 12, 366-373.

Miguel, M.G., Nunes, S., Dandhlen, S.A., Cavaco, A.M., Antunes, M.D., 2010. Phenols and antioxidant activity of hydro-alcoholic extracts of propolis from Algarve, South of Portugal. Food and Chemical Toxicology 48, 3418-3423.

Mirzoeva, O.K., Grishanin, R.N., Calder, P.C., 1997. Antimicrobial action of propolis and some of its components: the effects on growth, membrane potential and motility of bacteria. Microbiological Research 152, 239-246.

Morais, M., Moreira, L., Feás, X., Estevinho, L.M., 2011. Honeybee-collected pollen from five Portuguese Natural Parks: palynological origin, phenolic content, antioxidant properties and antimicrobial activity. Food and Chemical Toxicology 49, 1096-1101.

Moreira, L., Dias, L.G., Pereira, J.A., Estevinho, L., 2008. Antioxidant properties, total phenols and pollen analysis of propolis samples from Portugal. Food and Chemical Toxicology 46, 3482-3485.

Onlen, Y., Duran, N., Atik, E., Savas, L., Altug, E., Yakan, S.A., Aslantas, O., 2007. Antibacterial activity of propolis against MRSA and synergism with topical mupirocin. Journal of Alternative and Complementary Medicine 13, 713-718.

Park, Y.K., Alencar, S.M., Aguiar, C.L., 2002. Botanical origin and chemical composition of Brazilian propolis. Journal of Agricultural and Food Chemistry $50,2502-2506$

Park, Y.M., Koo, M.H., Abreu, J.A.S., Ikegagaki, M., Cury, J.A., 1998. Antimicrobial activity of propolis on oral microorganisms. Current Microbiology 36, 24-38.

Paulino, N., Dantas, A.P., Bankova, V., Longhi, D.T., Scremim, A., Castro, S.L., Calixto, J.B., 2003. Bulgarian propolis induces analgesic and anti-inflammatory effects in mice and inhibits in vitro contraction of airway smooth muscle. Journal of Pharmacological Sciences 93, 307-313.

Popova, M., Bankova, V., Butovska, D., Petkov, V., Nikolova-Damyanova, B., Sabatini, A., Marcazzan, G., Bogdanov, S., 2004. Validated methods for the quantification of biologically active constituents of poplar-type propolis. Phytochemical Analysis 15, 235-240.

Quiroga, E.M., Sampietro, D.A., Soberón, J.R., Sgariglia, M.A., Vattuone, M.A., 2006. Própolis from the northwest of Argentina as a source of antifungal principles. Journal of Applied Microbiology 101, 103-110.

Schnitzler, P., Neuner, A., Nolkemper, S., Zundel, C., Nowack, H., Sensch, K.H., Reichling, J., 2010. Antiviral activity and mode of action of propolis extracts and selected compounds. Phytotherapy Research 24, S20-28.

Silici, S., Kutluca, S., 2005. Chemical composition and antibacterial activity of propolis collected by three different races of honeybees in the same region. Journal of Ethnopharmacology 99, 69-73.

Tsuchiya, H., Iinuma, M., 2000. Reduction of membrane fluidity by antibacterial sophoraflavone G isolated from Sophora exigua. Phytomedicine 7, 161-165.

Umthong, S., Phuwapraisirisan, P., Puthong, S., Chanchao, C., 2011. In vitro antiproliferative activity of partially purified Trigona laeviceps propolis from Thailand on human cancer cell lines. BMC Complementary and Alternative Medicine 11, 30-37.

Valente, M.J., Baltazar, A.F., Henrique, R., Estevinho, L.M., Carvalho, M., 2011. Biological activities of Portuguese propolis: protection against free radicalinduced erythrocyte damage and inhibition of human renal cancer cell growth in vitro. Food and Chemical Toxicology 49, 86-92.

Vardar-Ünlü, G., Silici, S., Ünlü, M., 2008. Composition and in vitro antimicrobial activity of Populus buds and poplar-type propolis. World Journal of Microbiology and Biotechnology 24, 1011-1017.

Velazquez, C., Navarro, M., Acosta, A., Angulo, A., Dominguez, Z., Robles, R., RoblesZepeda, R., Lugo, E., Goycoolea, F.M., Velazquez, E.F., Astiazaran, H., Hernandez, J., 2007. Antibacterial and free-radical scavenging activities of Sonoran propolis. Applied Microbiology 103, 1747-1756. 